\title{
FIRE AND CLIMATE SUITABILITY FOR WOODY VEGETATION COMMUNITIES IN THE SOUTH CENTRAL UNITED STATES
}

\author{
Esther D. Stroh ${ }^{*}$, Matthew A. Struckhoff ${ }^{1}$, Michael C. Stambaugh ${ }^{2}$, \\ and Richard P. Guyette ${ }^{2}$ \\ ${ }^{1}$ US Geological Survey, Columbia Environmental Research Center, \\ 4200 New Haven Road, Columbia, Missouri 65201, USA \\ ${ }^{2}$ University of Missouri-Columbia, Department of Forestry, \\ 203 Anheuser-Busch Natural Resources Building, Columbia, Missouri 65211, USA \\ *Corresponding author: Tel.: +1-573-441-2944; e-mail: estroh@usgs.gov
}

ABSTRACT

Climate and fire are primary drivers of plant species distributions. Long-term management of south central United States woody vegetation communities can benefit from information on potential changes in climate and fire frequencies, and how these changes might affect plant communities. We used historical (1900 to 1929) and future (2040 to 2069 and 2070 to 2099) projected climate data for the conterminous US to estimate reference and future fire probabilities using a physical chemistry fire frequency model. We then used the fire probability data with additional climate parameters to construct maximum entropy environmental suitability models for three south central US vegetation communities. The modeled communities included an oak type (dominated by post oak, Quercus stellata Wangenh., and blackjack oak, Q. marilandica Münchh.), a mesquite type (dominated by honey mesquite, Prosopis glandulo$s a$ Torr., and velvet mesquite, $P$. veluti$n a$ Wooton), and a pinyon-juniper type (dominated by pinyon pine, Pinus edulis Engelm., and Utah juniper, Juniperus osteosperma [Torr.] Little). We
El clima y el fuego son los conductores primarios de la distribución de especies vegetales. El manejo a largo plazo de las comunidades vegetales leñosas del centro sur de los EEUU puede beneficiarse de la información sobre los cambios potenciales en el clima y en la frecuencia de fuegos, y sobre cómo estos cambios podrían afectar a estas comunidades. Nosotros utilizamos datos proyectados del clima histórico (1900 a 1929) y futuro (2040 a 2069 y 2070 a 2099) para todo el territorio de EEUU, para estimar probabilidades futuras y de referencia utilizando un modelo físico-químico de frecuencia de fuegos. Utilizamos entonces datos de probabilidad de fuego con parámetros de clima adicionales para construir modelos apropiados de máxima entropía ambiental para tres comunidades vegetales del centro-sur de EEUU. Las comunidades modeladas incluyeron un tipo de roble (dominado por roble de los postes, Quercus stellata Wangenh., y blackjack oak, Q. marilandica Münchh.), un tipo de mezquite (dominado por mezquite dulce Prosopis glandulosa Torr., y mezquite terciopelo, P. velutina Wooton), y un tipo de piñón-enebro (dominado por pino piñonero, Pinus edulis Engelm., y enebro de Utah Juniperus osteosperma [Torr.] Little). Mapeamos la línea base y el promedio ajusta- 
mapped baseline and future mean fire-climate suitability using data from three global climate models for 2040 to 2069 and 2070 to 2099; we also mapped future locations of threshold conditions for which all three models agreed on suitability for each community. Future projections included northward, southward, and eastward shifts in suitable conditions for the oaks along a broad path of fire-climate stability; an overall reduction in suitable area for historic mesquite communities coupled with potential expansion to new areas; and constriction and isolation of suitable conditions for pinyon-juniper communities. The inclusion of fire probability adds an important driver of vegetation distribution to climate envelope modeling. The simple models showed good fit, but future projections failed to account for future management activities or land use changes. Results provided information on potential future de-coupling and spatial re-arrangement of environmental conditions under which these communities have historically persisted and been managed. In particular, consensus threshold maps can inform long-term planning for maintenance or restoration of these communities, and they can be used as a potential tool for other communities in fire-prone environments within the study area and beyond its borders. do de clima y fuego a futuro utilizando datos de tres modelos climáticos globales de 2040 a 2069, y de 2070 a 2099; también mapeamos lugares que a futuro presenten condiciones límite y en los cuales los tres modelos coincidieron en ser apropiados para cada comunidad. Proyecciones futuras incluyeron cambios, en sentido norte, sur y este, en las condiciones apropiadas para los robles a lo largo de una amplia gama de estabilidades de clima y fuego; una reducción general en un área adecuada para comunidades históricas de mezquite, acopladas con una expansión potencial hacia nuevas áreas, y la retracción y aislamiento de condiciones apropiadas para comunidades de piñón-enebro. La inclusión de la probabilidad de fuego agrega un importante indicador de la distribución de la vegetación al modelado de cobertura climática. Los modelos simples mostraron un buen ajuste, pero las proyecciones en el tiempo fracasaron en explicar actividades futuras de manejo o cambios de uso de la tierra. Los resultados proveen de información sobre de potenciales disociaciones futuras y nuevos arreglos espaciales de las condiciones ambientales bajo las cuales estas comunidades han persistido históricamente $\mathrm{y}$ han sido manejadas. En particular, los mapas consensuados de límites pueden informar planes a largo plazo para el mantenimiento o la restauración de estas comunidades, y estos pueden ser utilizados como una herramienta potencial para otras comunidades en ambientes propensos al fuego dentro del área de estudio y también por fuera de sus límites.

Keywords: climate change, environmental suitability, fire frequency, fire probability, PC2FM, Pinus edulis, Prosopis glandulosa, Quercus stellata

Citation: Stroh, E.D., M.A. Struckhoff, M.C. Stambaugh, and R.P. Guyette. 2018. Fire and climate suitability for woody vegetation communities in the south central United States. Fire Ecology 14(1): 106-124. doi: 10.4996/fireecology.140110612 


\section{INTRODUCTION}

Climate and fire are global drivers of plant species distributions, and variations in climate and fire frequencies favor different species assemblages, or communities, at multiple scales (Woodward et al. 2004, Krawchuk et al. 2009, Parisien and Moritz 2009). In the south central United States, climate is a key factor in the historical high wildfire frequencies in east Texas and Oklahoma, as well as in the spatially variable historical wildfire frequency in west Texas and New Mexico (Guyette et al. 2012). The amount and type of vegetation determines the fuel load needed to sustain a fire; therefore, other climate-related environmental factors such as net primary productivity and ignition events can also affect fire probability (Krawchuk et al. 2009). Recent climate change has shifted the geographic ranges, distributions, and phenologies for many species at rapid rates, on every continent, and across most major taxa (Walther et al. 2002, Parmesan 2006, Chen et al. 2011, Bellard et al. 2012). Wildfire frequencies have increased in western US forests since the late twentieth century independent of land use and could continue to increase with projected climate trends (Westerling et al. 2006). Long-term management of regional vegetation communities can benefit from information on projected spatial changes in climate and fire frequencies. For example, future rearrangement of conditions under which certain communities have been dominant may expand or contract relative to historic patterns. Environmental suitability models can indicate where on the landscape future conditions favoring communities dominated by long-lived tree species might occur.

The need to understand which environmental drivers are most important to biota has led to the development of multiple approaches to species distribution modeling (SDM; for comprehensive descriptions of various approaches, see Franklin 2010). Climate envelope models include only climate variables to describe suitable abiotic conditions that support species; these can then be used with data from global climate models (GCMs) to project potential future locations for species under new climatic regimes (Hijmans and Graham 2006). Climate envelope models are not strictly SDMs because they do not explicitly include biological interactions or species traits; however, some species traits are implicit in the selected climate variables (Watling et al. 2013). For example, species' thermal limits are implicit in minimum and maximum temperature variables. Franklin (2010) examined 19 SDMs and found minimum temperature of the coolest month and maximum temperature of the warmest month used more frequently than mean annual maximum temperature; nearly all SDMs used total annual precipitation. Variables such as minimum and maximum temperatures do not describe the physical limits of a species, but rather, conditions under which a species persists in at least some multi-species communities (Thomas et al. 2004).

The primary objective of our work was to develop a simple model to relate fire probability and climate conditions to the historic distribution of important woody communities in Oklahoma, Texas, and New Mexico, USA, and project where on the landscape these conditions might occur in the future. The modeled communities included an oak type dominated by post oak (Quercus stellata Wangenh.) and blackjack oak ( $Q$. marilandica Münchh.), a mesquite type dominated by honey mesquite (Prosopis glandulosa Torr.) and velvet mesquite ( $P$. velutina Wooton), and a pinyon-juniper type dominated by pinyon pine (Pinus edulis Engelm.) and Utah juniper (Juniperus osteosperma [Torr.] Little). We developed fire-climate suitability models for each community, using climate and modeled fire conditions as inputs in the modeling freeware MAXENT 3.3.3k (Phillips et al. 2011). The inclusion of fire probabilities adds an important driver of vegetation distribution to envi- 
ronmental envelope modeling for woody communities in the south central US. We aimed to demonstrate an analytic approach that can be applied to other communities and provide information on potential future spatial rearrangements of environmental conditions under which these communities have historically persisted and have been managed.

\section{METHODS}

\section{Climate and Fire Probability Data}

We used 1900 to 1929 climate data in the Physical Chemistry Fire Frequency Model (PC2FM; Guyette et al. 2012) to model reference period fire probabilities and data from three global climate models (GCMs) to model future fire probabilities. Fire frequency calculations in PC2FM are based on a period of climate stretching back three centuries or more and calibrated using fire frequency data from over 170 sites across the US; the average scale of these fire frequency data is $1.2 \mathrm{~km}^{2}$ (Guyette et al. 2012). We identified 1900 to 1929 as a reference period because it represents the earliest dates of sufficient and available climate data for the study area and is closest to the period of European settlement in the study area. For future climate projections, we selected a midcentury (2040 to 2070) and a late century (2070 to 2099) period. We chose 30-year periods because climate data are commonly normalized this way, and a 30-year period allowed us to consider two future 30 -year periods within the twenty-first century.

We acquired $4 \mathrm{~km}$ gridded climate data for 1900 to1929 (PRISM 2014). For future climate data, we acquired $4 \mathrm{~km}$ gridded climate model output (bias corrected statistical downscaling method) from three global climate models for 2040 to 2069 and 2070 to 2099 (Idaho Interactive Numeric and Spatial Information Data Engine 2011). These data were generated by three GCMs: the GFDL-CM2.1 from the NOAA Geophysical Fluid Dynamics
Laboratory (2009), the CGCM 3.1 T47 from the Canadian Centre for Climate Modeling \& Analysis (Flato et al. 2000), and the UKMO-HadCM3 from the Hadley Centre for Climate Prediction and Research (Gordon et al. 2000). These models were chosen to represent a broad range of overall climate change projections and because they are considered suitable for use as input in ecological studies to assess regional climate change effects in the United States (Hayhoe 2013). The GCM model outputs are from the World Climate Research Programme's Coupled Model Intercomparison Project phase 3 multimodel dataset for the mid-emissions A1B scenario. We selected A1B because it represents a balanced future that does not rely too heavily on one particular energy source and assumes improvements to all energy supply and end use technologies (Intergovernmental Panel on Climate Change 2007a).

For reference, midcentury, and late century periods, the acquired climate data included mean annual precipitation $(\mathrm{cm})$, mean annual maximum temperature $\left({ }^{\circ} \mathrm{K}\right)$, January minimum temperature $\left({ }^{\circ} \mathrm{C}\right)$, and July maximum temperature $\left({ }^{\circ} \mathrm{C}\right)$ for the conterminous US. Mean annual precipitation and mean annual maximum temperature $\left({ }^{\circ} \mathrm{K}\right)$ from the historical period and projected values for these climate variables from each GCM and period were used to construct the environmental reaction rate and the reactant concentration parameters in PC2FM (Guyette et al. 2012) to derive mean fire intervals (MFI, years between fires). We then calculated mean fire probability as 1 $\div$ MFI to estimate the probability of a fire occurring in a given year for each $4 \mathrm{~km} \times 4 \mathrm{~km}$ grid cell averaged across the 30 -year period; approximately 16 PC2FM cells were averaged to provide a $4 \mathrm{~km}$ grid value.

\section{Woody Community Occurrence Data}

We selected Environmental Site Potential (ESP) data from the Landscape Fire and Re- 
source Management Planning Tools (LANDFIRE) Project as the best available data to characterize vegetation types under reference-period climate conditions. The ESP data provide fine-grained $(30 \mathrm{~m})$ wall-to-wall coverage of the conterminous US and are based on dominant and characteristic species that occur in each. The ESPs coincide with NatureServe's (2009) Ecological Systems and represent climax native vegetation communities in the absence of land use modification, reflecting reference climate, physical environment, plant biogeography, and native plant species competition (Comer et al. 2003). The ESP data are designed to support strategic planning at national, regional, and subregional scales (LANDFIRE 2014).

We calculated areas to identify the most abundant ESPs in Oklahoma, New Mexico, and Texas, USA, using the zonal toolset in ArcMap 10.3 (Environmental Systems Research Institute, Redlands, California, USA) and an Albers equal area projection; from these we selected nine woody ESPs representing about thirty percent of the study area (Table 1). We eliminated grassland and desert ESPs because they are not dominated by woody species; we eliminated woody floodplain ESPs because they rely on hydrologic processes that do not occur wall-to-wall at regional scales and could not be included in the model. We combined the nine woody ESPs into three woody communities for modeling, each dominated by the same species (Figure 1). The three communities represented a range of biophysical conditions (from mountains to plains), dominant physiognomic forms (shrublands and forests), and leaf habit (deciduous broadleaf and needle-leaved evergreens). The three woody communities were "oak," dominated by post oak and blackjack oak; "mesquite," dominated by honey mesquite and velvet mesquite; and "pinyon-juniper," dominated by pinyon pine and Utah juniper. We excluded the Edwards Plateau limestone savanna and woodland ESP because it is dominated by
Texas live oak (Quercus fusiformis Small), Lacey oak $(Q$. laceyi Small), sandpaper oak (Q. vaseyana Buckley), Ashe's juniper (Juniperus ashei J. Buchholz), or papershell pinyon (Pinus remota [Little] D.K. Bailey \& Hawksw.). NatureServe (2009) provides full descriptions for each Ecological System shown in Table 1, using nomenclature identical to the ESP names.

For input into MAXENT, we converted the ESP raster to point data to represent community occurrence records. To do this, the $30 \mathrm{~m}$ raster was resampled for each selected ESP using the resample tool and the "majority" algorithm at a resolution of $1 \mathrm{~km}$ in the raster processing toolset in ArcMap. This algorithm produced a $1 \mathrm{~km}$ raster in which pixel classification was determined by the most frequent ESP value within the filter window; this method eliminated any pixels that fell within any 1 $\mathrm{km}$ filter window in which that ESP was not the majority type. The resulting raster was then converted to points corresponding with pixel centers using the geoprocessing toolbox in ArcMap.

\section{Environmental Suitability Modeling}

Raster grids for 1900 to 1929 mean fire probability (natural-log transformed to increase normality), annual precipitation, January minimum temperature, July maximum temperature, and community point data were used in MAXENT to build reference fire-climate suitability models for each ecosystem. MAXENT uses known occurrences of a species with environmental predictor variables to calculate a probability distribution of maximum entropy (most spread out or uniform) for that species over an area greater than that of its known occurrences (Phillips and Dudík 2008). The assumption is that expected values of each environmental predictor variable are equivalent to the empirical mean of its value in sites of known occurrence (Phillips et al. 2006). Presence-only models such as MAXENT as- 
Table 1. Primary ecological site potential (ESP) types and community groupings in three south central US states: Oklahoma (OK), New Mexico (NM), and Texas (TX). Oak, mesquite, and pinyon-juniper community groups were selected for environmental suitability modeling.

\begin{tabular}{|c|c|c|c|c|c|}
\hline \multirow[b]{2}{*}{ Environmental site potential name } & \multirow[b]{2}{*}{ Community } & \multicolumn{4}{|c|}{ Area $\left(\mathbf{k m}^{2}\right)$} \\
\hline & & OK & NM & TX & Total \\
\hline $\begin{array}{l}\text { Western Great Plains mesquite woodland } \\
\text { and shrubland }\end{array}$ & mesquite & 5045 & 7734 & 77441 & 90219 \\
\hline Western Great Plains shortgrass prairie & grassland & 8042 & 40253 & 39836 & 88132 \\
\hline $\begin{array}{l}\text { Apacherian Chihuahuan mesquite upland } \\
\text { scrub }\end{array}$ & mesquite & 0 & 24186 & 37971 & 62156 \\
\hline Western Great Plains sandhill steppe & grassland & 9593 & 11665 & 35752 & 57010 \\
\hline Crosstimbers oak forest and woodland & oak & 32441 & 0 & 20207 & 52647 \\
\hline Southeastern Great Plains tallgrass prairie & grassland & 45251 & 0 & 6504 & 51755 \\
\hline Tamaulipan mixed deciduous thorn scrub & mesquite & 0 & 0 & 47708 & 47708 \\
\hline Western Great Plains floodplain systems & floodplain & 17731 & 3081 & 26477 & 47289 \\
\hline Chihuahuan creosotebush desert scrub & desert & 0 & 19438 & 25617 & 45055 \\
\hline Chihuahuan mixed desert and thorn scrub & desert & 0 & 16056 & 27841 & 43897 \\
\hline $\begin{array}{l}\text { Edwards Plateau limestone savanna and } \\
\text { woodland }\end{array}$ & oak* & 16 & 0 & 42589 & 42606 \\
\hline Colorado Plateau pinyon-juniper woodland & $\begin{array}{l}\text { pinyon- } \\
\text { juniper }\end{array}$ & 0 & 38926 & 0 & 38926 \\
\hline $\begin{array}{l}\text { Gulf and Atlantic coastal plain floodplain } \\
\text { systems }\end{array}$ & floodplain & 1314 & 0 & 33613 & 34926 \\
\hline Southern blackland tallgrass prairie & grassland & 381 & 0 & 32330 & 32711 \\
\hline Central mixed grass prairie & grassland & 16058 & 2211 & 14168 & 32438 \\
\hline $\begin{array}{l}\text { East central Texas plains post oak savanna } \\
\text { and woodland }\end{array}$ & oak & 40 & 0 & 28523 & 28563 \\
\hline $\begin{array}{l}\text { Southern Rocky Mountain pinyon-juniper } \\
\text { woodland }\end{array}$ & $\begin{array}{l}\text { pinyon- } \\
\text { juniper }\end{array}$ & 178 & 27242 & 3 & 27423 \\
\hline Tamaulipan mesquite upland scrub & mesquite & 0 & 0 & 4835 & 4835 \\
\hline Colorado Plateau pinyon-juniper shrubland & $\begin{array}{l}\text { pinyon-- } \\
\text { juniper }\end{array}$ & 0 & 365 & 0 & 365 \\
\hline Proportion of study area & & & & & 0.30 \\
\hline
\end{tabular}

sume that the environment at occupied sites is suitable for a given species, and sites outside of the known occurrences represent the range of available environmental conditions, sometimes called pseudo-absences (Franklin 2010). Therefore, the prediction is relative habitat suitability, rather than occurrence probability
(Phillips et al. 2006). MAXENT is robust to limited amounts of training data (Phillips and Dudík 2008); models with as few as three predictor variables have been found to produce nearly identical results to a mechanistic model independent of occurrence data (Kearney et al. 2010). MAXENT models have produced "rea- 


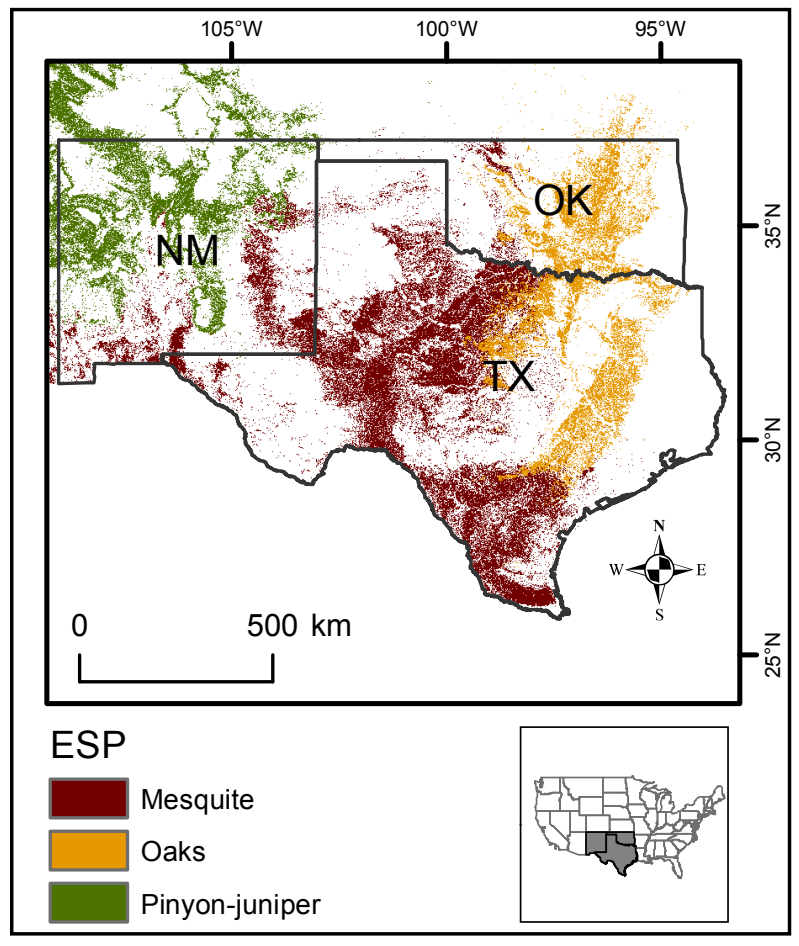

Figure 1. Distribution of mesquite, oak, and pinyon-juniper environmental site potential (ESP) types in the study area of New Mexico (NM), Texas (TX), and Oklahoma (OK), USA.

sonably good" projections of species' range shifts under climate change (false positive rate $\leq 0.01$, false negative rate $=0.15$ to 0.85 ; Hijmans and Graham 2006). The ESP dataset (LANDFIRE 2014) is a wall-to-wall model of ESP "occurrences;" the pixels used to extract our sampling points essentially represent the full distribution of each ecosystem, because all ESP pixels are classified, and each of them is or is not the modeled community. Prior to running MAXENT, all variables were screened for collinearity by constructing a Pearson correlation matrix using SYSTAT Version 13 (Systat Software, San Jose, California, USA).

We used the MAXENT logistic output format (generating environmental suitability values between 0 and 1), a random test percentage of $30 \%$ (using $70 \%$ of the occurrence points to generate the suitability model and $30 \%$ of the occurrence points to test it), 500 iterations per run, 10000 random background points, and a jackknife test to measure variable importance. We selected "do not skip duplicates" option; this means that the $1 \mathrm{~km}$ scale of the community point data could give as many as 16 occurrence points in a single 4 $\mathrm{km}$ fire-climate grid cell, essentially a measure of the density or spatial coverage of a community under those environmental conditions. We used a 10-fold cross-validation routine with repeated subsampling of occurrence points into random training and testing subsets. This generated 10 separate models plus an averaged model with summarized statistical information for each cross-validation run, which is at the upper end of 5 to 10 partitions needed to reduce the variance of parameter estimates (Phillips and Dudík 2008). The models that were trained on the reference period variables were then used to project environmental suitability for each community for each GCM and future period.

We used area under the receiver operating characteristic curve (AUC) values generated by the routine that tests the model with the $30 \%$ withheld data to assess model performance. The AUC metric ranges from 0 to 1 and is the probability that a randomly chosen occupied site has a higher suitability value than a randomly chosen background site. An AUC value less than or equal to 0.5 represents a random result; a perfect result would achieve an AUC of 1.0 (Phillips et al. 2006). We assessed the importance of individual variables in each model by examining permutation importance (percent decrease in AUC when both presence and background training values of a variable are randomly shuffled) and the jackknifed test that AUC values achieved without each variable and with each variable individually. The test AUC values for individual variables indicated which were most effective for predicting distribution of the $30 \%$ set-aside data points; the higher the contribution to the AUC, the more influence that particular variable had on predicting environmental suitability for that community. 


\section{Fire-Climate Suitability and Consensus Threshold Mapping}

The cross-validated model outputs are rasters with $4 \mathrm{~km}$ cell values of fire-climate suitability estimates (between 0 and 1) for each community using data from 1900 to 1929 and from each GCM at each future period. Outputs from the three GCMs for each community were averaged into a single raster to give mean fire-climate suitability for each future period. We used these values to construct maps that display future mean fire-climate suitability for each community for 2040 to 2069 and 2070 to 2099.

Because the three GCMs projected varied future conditions for a given location, we also constructed maps to show where all three fire-climate models met or exceed threshold values for each community for a given future period. We used the equal test sensitivity and specificity (ETSS) logistic threshold values from the MAXENT results to set the threshold value. The ETSS logistic threshold maximizes sensitivity (reducing false negatives) and specificity (reducing false positives), making it a good choice for presence-only models (Liu et al. 2005). We combined the rasters for each community within each future period and classified as "suitable" all cells for which all three GCM suitability values were greater than or equal to the ETSS logistic threshold; all other cells were classified as "unsuitable."

\section{RESULTS}

\section{Fire Probability Maps}

Reference period output from the PC2FM model (Guyette et al. 2012) show fire probabilities in the eastern portion of the study area to be among the highest in the US, in excess of 0.30 (MFI $\leq 3.33 \mathrm{yr}$ ). Western portions of the study area show low fire probabilities (less than 0.10 , MFI $>10 \mathrm{yr}$ ) with pockets of moderate fire probability $(0.25$ to $0.10 ; \mathrm{MFI}=4 \mathrm{yr}$ to $10 \mathrm{yr}$; Figure 2). Future projections by all three GCMs are for generally increasing fire probabilities in midcentury with further increases in late century (Figure 2). Detailed analysis of changes in fire probabilities across the study area are presented elsewhere (Stambaugh et al. 2018).

\section{Fire-Climate Envelope Models}

Pearson correlation coefficients among the variables used in the MAXENT model were: July maximum temperature with January minimum temperature, 0.53 ; July maximum temperature with annual precipitation, -0.47 ; annual precipitation with fire probability, -0.29 ; and July maximum temperature and fire probability, 0.22. All other pairwise correlation coefficients were smaller. None of the correlations was considered a concern for the model; warm areas have higher temperatures in both January and July, and wet summer conditions produce less sunshine and more evaporative cooling (Intergovernmental Panel on Climate Change 2007b).

All three fire-climate suitability models had very good fit as measured by their test AUC values. The mean test AUC values for the MAXENT cross-validation replicate runs were: oak, 0.984; mesquite, 0.970; and pinyon-juniper, 0.927. Annual precipitation had the highest permutation importance for all community models (Table 2). Variables that contributed the most information when used in isolation were: for oaks, fire probability and July maximum temperature; for mesquite, July maximum temperature; and for pinyon-juniper, annual precipitation (Table 2).

\section{Fire-Climate Suitability and Threshold Maps}

The fire-climate suitability maps generated from model outputs indicate where climate and fire conditions are projected to be favorable for a community, not its predicted distribution. The data used to construct suitability 


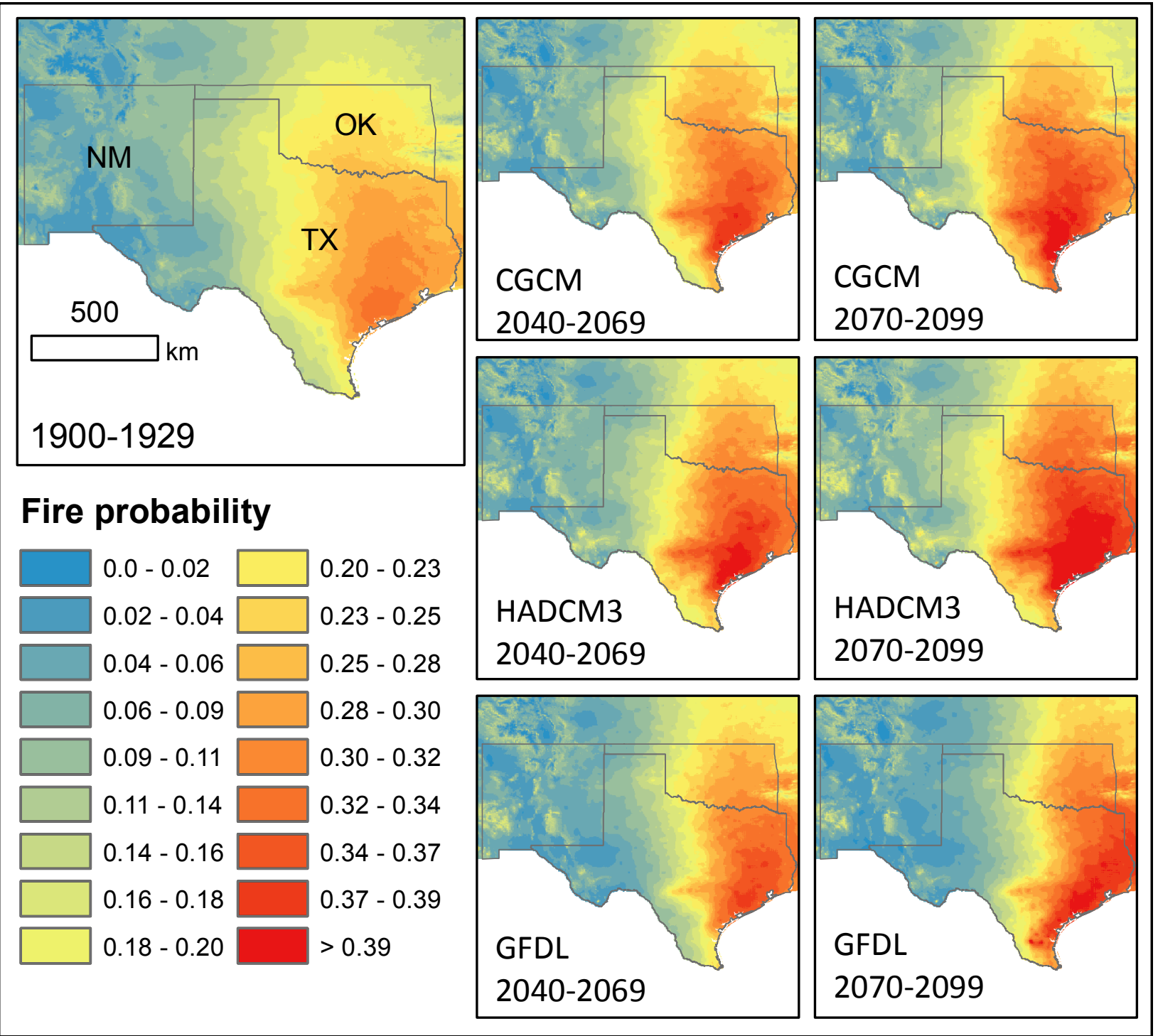

Figure 2. Fire probability in New Mexico (NM), Texas (TX), and Oklahoma (OK), USA, for 1900 to 1929, 2040 to 2069, and 2070 to 2099 generated by the Physical Chemistry Fire Frequency Model with data from three global climate models (GFDL, CGCM, and HADCM3).

maps for future periods represent the mean value from the three fire-climate models for that period. Fire-climate suitability values for each community for 1900 to 1929 and for each future period-GCM combination are available online (Stroh et al. 2018)

The range and distribution of future fire-climate suitability conditions relative to reference locations differed for the three modeled community types. Reference period fire-climate suitability for oaks is shown in
Figure 3A. Future mean suitability maps for oaks projected that favorable conditions will expand northward and eastward by midcentury (Figure 3B). Suitable conditions for oaks were projected to expand southward in Texas and shift farther northward and eastward, with increasing area of high suitability $(\geq 6.0)$ in late century (Figure 3C). Reference period fire-climate suitability for mesquite is shown in Figure 3D. In midcentury, there was some north and westward expansion of low (0.2 to 0.4$)$ to 
Table 2. Number of model training and test points, model results, and variable performance for MAXENT models of fire-climate suitability for three south central US vegetation communities. AUC = area under the receiver operating characteristic curve, $\mathrm{SD}=$ standard deviation, $\mathrm{ETSS}=$ equal test sensitivity and specificity, $\mathrm{ppt}=$ precipitation, $\mathrm{T}$ $\min =$ minimum temperature, $\mathrm{T} \max =$ maximum temperature.

\begin{tabular}{|c|c|c|c|}
\hline & Oak & Mesquite & $\begin{array}{l}\text { Pinyon- } \\
\text { juniper }\end{array}$ \\
\hline \multicolumn{4}{|c|}{ Community occurrence points } \\
\hline Training points $(n)$ & 688 & 1868 & 1570 \\
\hline Test points $(n)$ & 294 & 800 & 672 \\
\hline \multicolumn{4}{|c|}{ Overall model results } \\
\hline Training AUC & 0.9873 & 0.9726 & 0.9311 \\
\hline Test AUC & 0.9839 & 0.9696 & 0.9267 \\
\hline AUC SD & 0.0019 & 0.0016 & 0.0035 \\
\hline $\begin{array}{l}\text { ETSS logistic } \\
\text { threshold }\end{array}$ & 0.1344 & 0.2487 & 0.3306 \\
\hline \multicolumn{4}{|c|}{ Performance of individual variables } \\
\hline \multicolumn{4}{|c|}{ Permutation importance $(\%)$} \\
\hline Annual ppt (cm) & 58.1895 & 58.7840 & 68.0197 \\
\hline January $\mathrm{T} \min \left({ }^{\circ} \mathrm{C}\right)$ & 8.0502 & 22.8078 & 19.8425 \\
\hline July T max $\left({ }^{\circ} \mathrm{C}\right)$ & 14.8504 & 12.5358 & 5.6574 \\
\hline Fire probability & 18.9098 & 5.8723 & 6.4803 \\
\hline \multicolumn{4}{|c|}{ Test AUC without variable } \\
\hline Annual ppt (cm) & 0.9782 & 0.9582 & 0.8667 \\
\hline January $\mathrm{T} \min \left({ }^{\circ} \mathrm{C}\right)$ & 0.9829 & 0.9638 & 0.9100 \\
\hline July T max $\left({ }^{\circ} \mathrm{C}\right)$ & 0.9824 & 0.9630 & 0.9204 \\
\hline Fire probability & 0.9836 & 0.9682 & 0.9231 \\
\hline \multicolumn{4}{|c|}{ Test AUC with only variable } \\
\hline Annual ppt (cm) & 0.8856 & 0.8007 & 0.8605 \\
\hline January $\mathrm{T} \min \left({ }^{\circ} \mathrm{C}\right)$ & 0.8528 & 0.8740 & 0.7818 \\
\hline July T max $\left({ }^{\circ} \mathrm{C}\right)$ & 0.9458 & 0.9295 & 0.7126 \\
\hline Fire probability & 0.9485 & 0.7160 & 0.7397 \\
\hline
\end{tabular}

moderate $(0.4$ to 0.6$)$ fire-climate suitability and decreasing area of high suitability $(\geq 0.6)$ in central and south Texas (Figure 3E). Late century showed further declines in area with moderate and high suitability and loss of midcentury low suitability areas in and north of Oklahoma (Figure 3F). Reference period fire-climate suitability for pinyon-juniper is shown in Figure 3G. Only three $4 \mathrm{~km}^{2}$ pixels in New Mexico (not discernible in the figure) achieved a suitability score of 0.8 or greater in the reference period. In midcentury, areas of high suitability $(\geq 0.6$ ) for pinyon-juniper decreased relative to the reference period and areas of low (0.2 to 0.4$)$ and moderate ( 0.4 to 0.6) fire-climate suitability disappeared from eastern New Mexico (Figure 3H). Late century maps showed a similar footprint to that in midcentury, but with further decreases in suitability values and total area, combined with increased fragmentation of suitable conditions (Figure 3I).

Suitability threshold maps for the reference period indicated areas in which fire-climate suitability scores met or exceeded the ETSS logistic threshold for a given community (oak $=0.1344$, mesquite $=0.2487$, pinyonjuniper $=0.3306$ ). For the reference period, these areas encompassed and expanded beyond the points used to generate the model for oaks (Figure 4A), mesquite (Figure 4D), and pinyon-juniper (Figure 4G). Suitability threshold maps for future periods indicated where all three fire-climate models met or exceeded the ETSS threshold for a given community. In midcentury, threshold areas for oaks expanded northward and constricted along a north-south line in Texas and Oklahoma (Figure 4B), followed by further narrowing with southward, northward, and eastward expansion in late century (Figure 4C). In midcentury, areas of threshold suitability for both mesquite (Figure 4E) and pinyon-juniper (Figure $4 \mathrm{H}$ ) decreased substantially relative to the reference period. In late century, threshold areas for mesquite contracted further and dis- 


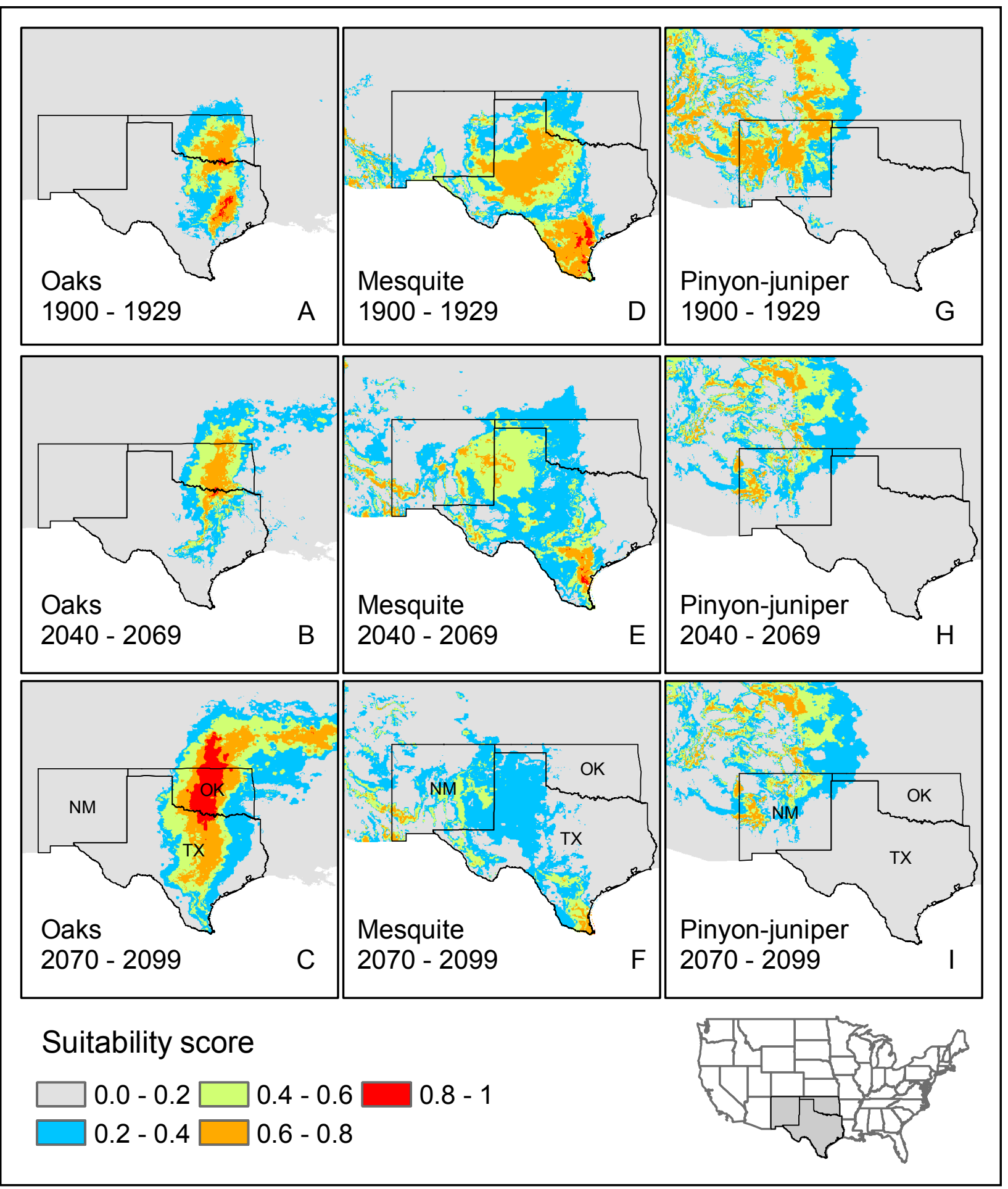

Figure 3. Fire-climate suitability scores for three environmental site potential types in New Mexico (NM), Texas (TX), and Oklahoma (OK), USA, at three periods. Top row: reference period suitability. Middle row: mean suitability score for 2040 to 2069 averaged from three fire-climate suitability models. Bottom row: mean suitability score for 2070 to 2099 averaged from three fire-climate suitability models. 

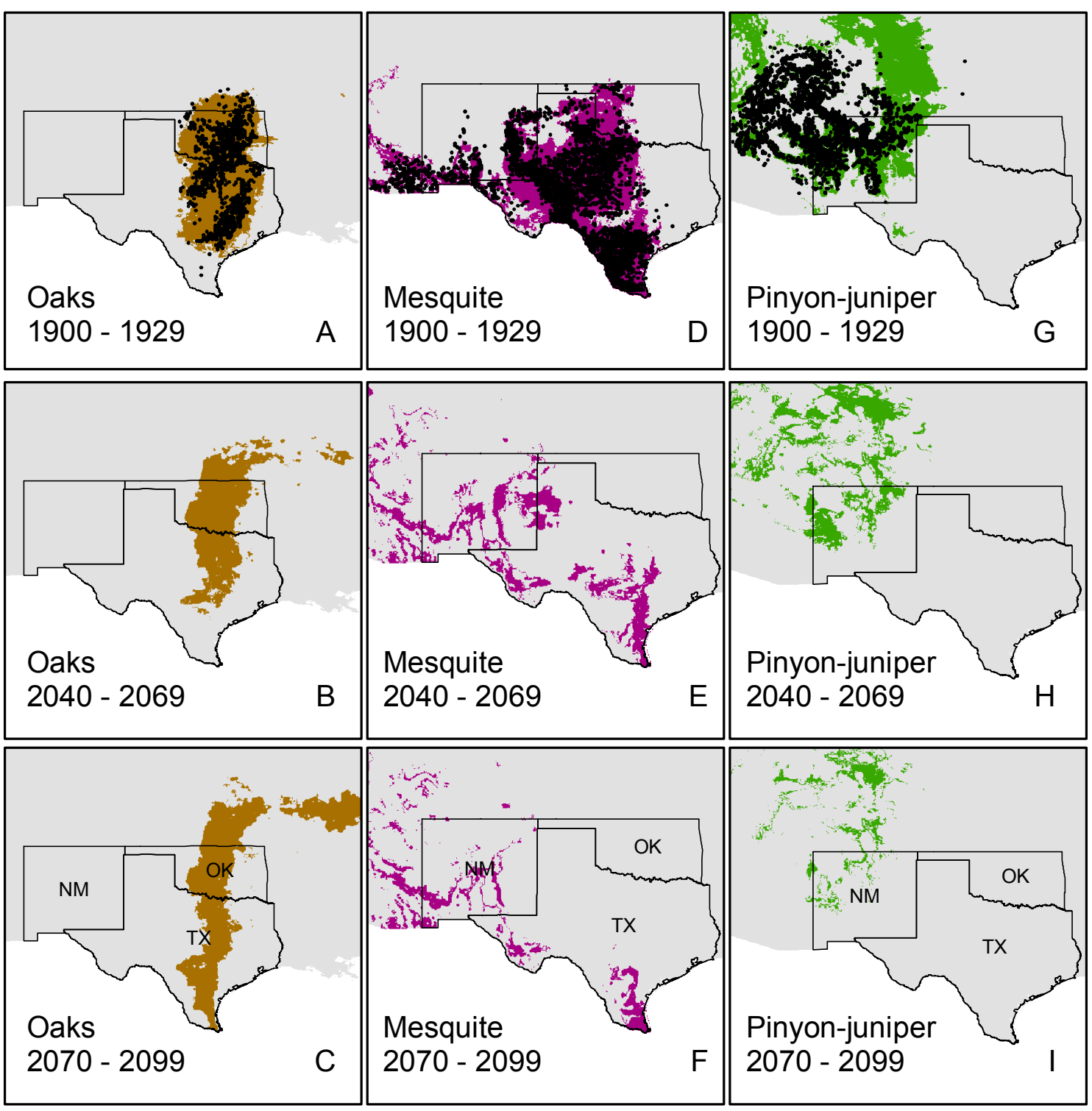

- Points used to model $1900-1929$

environmental suitability

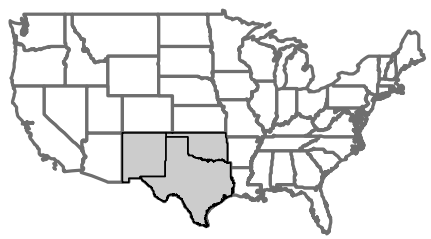

Figure 4. Fire-climate suitability threshold and consensus threshold maps for three environmental site potential types in New Mexico (NM), Texas (TX), and Oklahoma (OK), USA, at three periods. Colored areas indicate where fire-climate suitability scores met or exceeded the equal test sensitivity (ETSS) logistic threshold for a given ecosystem. Top row: reference period suitability threshold areas. Black dots indicate locations of occurrence points used to build the suitability models. Middle row: consensus threshold areas where suitability scores from all models utilizing 2040 to 2069 data from three global climate models met or exceeded ETSS threshold. Bottom row: consensus threshold areas where suitability scores from all models utilizing 2070 to 2099 data from three global climate models met or exceeded ETSS threshold. 
appeared from central Texas and much of the Texas-New Mexico border (Figure 4F). Consensus areas of threshold suitability for pinyon-juniper became increasingly patchy, occupying little area in late century (Figure 4I).

When taken together, model output of fire-climate suitability for the 1900 to 1929 reference period shows a large overlapping area of suitability for mesquite and oak along a north-south line in central Texas and a small overlapping area of suitability for mesquite and pinyon-juniper in east-central New Mexico (Figure 5A). Projected fire-climate suitability in the study area declined sharply for all communities in midcentury; total area in 2040 to 2069 relative to 1900 to 1929 was $55 \%$ for oaks, $29 \%$ for mesquite, and $30 \%$ for pinyon-juniper (Figure 5B). Further areal declines in fire-climate suitability were projected for all communities in late century; total area in 2070 to 2099 relative to 1900 to 1929 was
$51 \%$ for oaks, $13 \%$ for mesquite, and $7 \%$ for pinyon-juniper (Figure 5C). In spite of the shrinking area of suitability across the board, all models agreed on the stability of fire-climate suitability for oaks along a north-south line from central Oklahoma to south Texas, in south and southwest Texas for mesquite, and in scattered patches in New Mexico for mesquite and pinyon-juniper (Figure 5B and 5C).

\section{DISCUSSION}

Our results projected potential future locations of fire-climate suitability for three common woody communities in the south central US. Using results from climate envelope models to predict future ranges under new climatic conditions can be fraught with uncertainty due to broad assumptions made about species' dispersal abilities, biotic interactions, habitat availability, phenological changes, and
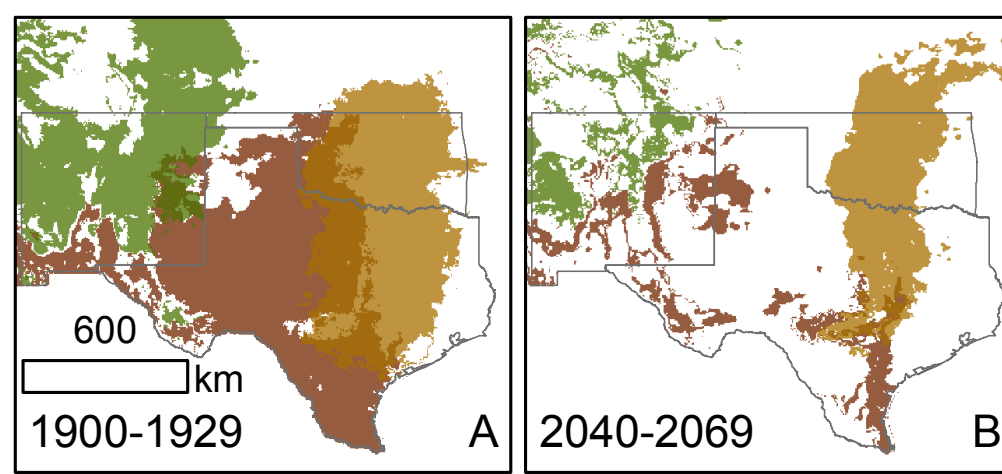

$\mathrm{B}$

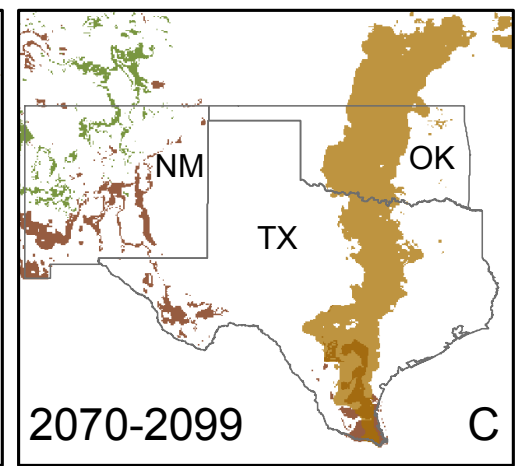

Suitability thresholds Oaks Pinyon-juniper

Mesquite Unsuitable

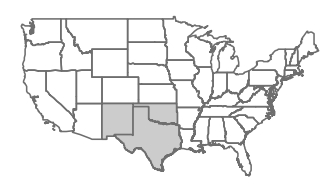

Figure 5. Future loss and stability of fire-climate suitability conditions for three environmental site potential types in New Mexico (NM), Texas (TX), and Oklahoma (OK), USA. Colored areas indicate where fire-climate suitability scores met or exceeded the equal test sensitivity (ETSS) logistic threshold for a given ecosystem. A: reference period threshold areas for oaks, mesquite, and pinyon-juniper. B: consensus threshold areas where suitability scores from all models utilizing 2040 to 2069 data from three global climate models met or exceeded ETSS threshold shift northward for oaks and decline sharply for mesquite and pinyon-juniper. C: consensus threshold areas in 2070 to 2099, consensus threshold areas for oaks constrict centrally but expand south and farther north; consensus threshold areas for both mesquite and pinyon-juniper become smaller and more isolated. 
other unknowns (Araújo et al. 2005). Environmental suitability alone does not guarantee that a community will actually occur in a given location (Watling et al. 2013), and intended applications for environmental suitability models should be explicit (Jeschke and Strayer 2008). Here we assessed projected future changes in area and spatial arrangements of fire-climate conditions associated with reference distributions of communities as a way to understand the magnitude of potential changes from conditions under which these communities have been managed.

Our models used three climate variables and fire probabilities and showed good fit regarding environmental suitability for each community we assessed. Our results projected large future reductions in total area of fire-climate suitability for all modeled community types, indicating a de-coupling and spatial re-arrangement of conditions that supported these communities in the reference period and under which they have been historically dominant and managed. Our results also showed consensus among three models regarding areas of continued suitability through the twenty-first century. For resource management actions intended to maintain healthy vegetation communities over long periods, it is useful to know what climatic conditions have supported communities in the recent past, and where, in the future, similar climatic conditions will likely occur. Current threats to the modeled oak communities are agricultural conversion, fire suppression, and invasion by eastern redcedar (Juniperus virginiana L.), mesquite, or annual grasses (Comer et al. 2003). Mesquite communities are not considered threatened; with fire suppression, grazing, and seed dispersal by livestock, mesquite has extend its range and density into historical prairie communities and desert grasslands (Teague et al. 1997). Pinyon-juniper woodlands are widespread and abundant in the American West; however, rapid regional die-off of pinyon pine can occur following drought, unusually warm temperatures, and subsequent bark beetle infestation (Breshears et al. 2005).

Fire-climate conditions that favor oak communities are projected to remain stable in central Texas and Oklahoma, with future southward expansion, as well as north and east into the historic prairie peninsula. Where these oak communities are already present or desired, this is advantageous, and may represent restoration or conservation opportunities. Prescriptions for maintaining and restoring structure to long unburned oak woodlands are described in Sparks et al. (2012). Conversely, where these communities are not desired, additional management activities and resources may be required to limit woody stem encroachment to maintain rangelands or prairie types.

Areas of suitable fire-climate conditions favoring mesquite in central Texas were projected to decrease significantly; those in the western part of the study area are projected to shift northward and decrease in total. However, climate data were not available for Mexico, which includes the bulk of the native range for the mesquite community considered in this study. Therefore, the fire-climate envelope for mesquite was developed without a full data set, with the greatest uncertainty at the southern edges of the projected suitability map. Mesquite is a problematic species; its presence can reduce desirable rangeland grass species (Teague et al. 1997). In the twentieth century, mesquite density increased significantly within its historical range and in new areas due primarily to management activities such as fire suppression and dispersal by cattle (Wilson et al. 2001). Future northward shifts of fire-climate suitability in mid and late century indicated new areas of potential mesquite colonization. Mesquite will likely continue to present rangeland management challenges in its current range and in areas not yet occupied.

Suitability maps for pinyon-juniper showed large decreases in suitable area in midcentury, and further decreases in late century. 
Suitable areas became increasingly fragmented and isolated; managers could be faced with vulnerable communities where the type is currently abundant. The reference fire-climate suitability map for pinyon-juniper illustrated the lower performance of that model and included a large area to the northwest that does not contain points used to construct the model. However, this area includes the Great Basin pinyon-juniper woodland ESP, dominated by pure stands of a different pine species, singleleaf pinyon (Pinus monophylla Torr. \& Frém.), or singleleaf pinyon mixed with Utah juniper (NatureServe 2009); this community may share a similar fire-climate envelope. Single-leaf pinyon and Utah juniper, along with western juniper (Juniperus occidentalis Hook.), have encroached upon or replaced sagebrush steppe communities in the Great Basin due to a variety of factors, including climate changes and disrupted fire regimes (Miller et al. 2008). The modeled future decline in areal extent of suitable conditions to the northwest may affect further expansion. Within the heart of the pinyon-juniper range in New Mexico, where areas of suitability sharply constrict, surviving stands outside suitable areas may support new or surviving stands within future suitable areas. Scattered trees may facilitate climate adaptation by providing seed sources and secondary habitat outside reserves (Manning et al. 2009).

Our results are relevant for a $4 \mathrm{~km}^{2}$ scale; different results are possible where finer-scale climate data are available. Information detailing the effect of scale on fire frequency is limited. Falk et al. (2007) and Stambaugh et al. (2016) addressed influence of scale on fire frequency data that generally follows a power law with finer scales having longer MFIs. Further work is needed, particularly along gradients of vegetation cover and substrate that affect fire spread (Turner and Romme 1994). Other important factors may include time, climate, or interacting disturbances that influence fuel abundance and condition (Swetnam and
Betancourt 1990, Veblen et al. 2000, Fleming et al. 2002). Based on simulations, changes in fire intervals in Western conifer forests (MFIs and Weibull Median Probability Intervals) from $1 \mathrm{~km}^{2}$ to $4 \mathrm{~km}^{2}$ are $<2 \mathrm{yr}$ (McKenzie et al. 2006, Falk et al. 2007). Based on Stambaugh et al. (2016), mean fire intervals in central US oak forests would decrease by less than $1 \mathrm{yr}$ from the scale of $1 \mathrm{~km}^{2}$ to $4 \mathrm{~km}^{2}$. In summary, it is not clear whether systematic errors or noise would propagate to multi-level spatial analyses, although it is possible.

Future human activities may affect changes that are not predicted by our model outputs. For example, habitat fragmentation can inhibit the flow of desired or prescribed fires across the landscape, and non-native vegetation can move fire regimes out of the range of historic variation and into new ecological states (Moritz et al. 2013). The PC2FM (Guyette et al. 2012) is a physical chemistry model that does not account for future unknowns such as landscape fragmentation or management activities. The PC2FM does not predict actual fire occurrence in a given location but, rather, the probability of fire given the physical environment, in the absence of human modification. Likewise, ESPs describe potential native vegetation communities in the absence of human modification, not existing land cover (Comer et al. 2003). Nevertheless, the modeling approach can be used to understand climate-related and fire-related pressures that will affect management of woody communities, isolating climate and fire influences from other factors. Given current fragmentation and land cover conditions, the landscape in New Mexico provides much more connectivity than does the rest of the study area, especially east Texas and all of Oklahoma (McGuire et al. 2016). This is important to consider as the areal extent of suitable conditions for these communities diminish.

Locations that show future unfavorable conditions for oaks, mesquite, or pinyon-juniper may have environmental conditions favor- 
ing other community types. However, continued persistence of existing examples of these communities under new fire-climate conditions may be possible considering the relatively long lifespan (100 yr to $600 \mathrm{yr}$ ) of the principal species. For example, mature individuals may survive intact or their roots may resprout for long periods under less than optimal conditions of climate or changed fire regime. However, whether these communities can continue to reproduce and recruit new individuals in-si$t u$ under new fire-climate regimes remains to be seen. The loss or rearrangement of areas meeting the fire-climate conditions under which the three communities have historically persisted is evident when comparing reference and future suitability threshold maps. In particular, maps that show consensus among all models regarding continued environmental suitability through the twenty-first century can inform long-term planning for maintenance or restoration of these communities, indicating locations in which they might be maintained, restored, or established.

\section{ACKNOWLEDGEMENTS}

This project was funded in part by the US Geological Survey South Central Climate Science Center, in cooperation with the University of Missouri-Columbia and the Great Rivers Cooperative Ecosystems Studies Unit. We acknowledge the modeling groups, the Program for Climate Model Diagnosis and Intercomparison and the Working Group on Coupled Modelling, for their roles in making available the multi-model data set. Support of this dataset is provided by the Office of Science, US Department of Energy. Any use of trade, firm, or product names is for descriptive purposes only and does not imply endorsement by the US Government.

\section{LITERATURE CITED}

Araújo, M.B., R.G. Pearson, W. Thuiller, and M. Erhard. 2005. Validation of species-climate impact models under climate change. Global Change Biology 11: 1504-1513. doi: 10.1111/j.1365-2486.2005.01000.x

Bellard, C., C. Bertelsmeier, P. Leadley, W. Thuiller, and F. Courchamp. 2012. Impacts of climate change on the future of biodiversity. Ecology Letters 15: 365-377. doi: 10.1111/j.1461-0248.2011.01736.x

Breshears, D.D., N.S. Cobb, P.M. Rich, K.P. Price, C.D. Allen, R.G. Balice, W.H. Romme, J.H. Kastens, M.L. Floyd, J. Belnap, J.J. Anderson, O.B. Myers, and C.W. Meyer. 2005. Regional vegetation die-off in response to global-change-type drought. Proceedings of the National Academy of Sciences of the United States of America 102: 15144-15148. doi: 10.1073/ pnas.0505734102

Chen, I., J.K. Hill, R. Ohlemüller, D.B. Roy, and C.D. Thomas. 2011. Rapid range shifts of species associated with high levels of climate warming. Science 333: 1024-1026. doi: 10.1126/ science. 1206432

Comer, P., D. Faber-Langendoen, R. Evans, S. Gawler, C. Josse, G. Kittel, S. Menard, M. Pyne, M. Reid, and K. Schulz. 2003. Ecological systems of the United States: a working classification of US terrestrial systems. NatureServe, Arlington, Virginia, USA.

Falk, D.A., C. Miller, D. McKenzie, and A.E. Black. 2007. Cross-scale analysis of fire regimes. Ecosystems 10: 809-823. doi: 10.1007/s10021-007-9070-7

Flato, G.M., G.J. Boer, W.G. Lee, N.A. McFarlane, D. Ramsden, M.C. Reader, and A.J. Weaver. 2000. The Canadian Centre for Climate Modelling and Analysis global coupled model and its climate. Climate Dynamics 16: 451-467. doi: 10.1007/s003820050339 
Fleming, R.A., J.-N. Candau, and R.S. McAlpine. 2002. Landscape-scale analysis of interactions between insect defoliation and forest fire in central Canada. Climatic Change 55: 251272. doi: 10.1023/A:1020299422491

Franklin, J. 2010. Mapping species distributions: spatial inference and prediction. Cambridge University Press, New York, New York, USA. doi: 10.1017/CBO9780511810602

Gordon, C., C. Cooper, C.A. Senior, H. Banks, J.M. Gregory, T.C. Johns, J.F.B. Mitchell, and R.A. Wood. 2000. The simulation of SST, sea ice extents and ocean heat transports in a version of the Hadley Centre coupled model without flux adjustments. Climate Dynamics 16: 147-168. doi: 10.1007/s003820050010

Guyette, R.P., M.C. Stambaugh, D.C. Dey, and R.-M. Muzika. 2012. Predicting fire frequency with chemistry and climate. Ecosystems 15: 322-335. doi: 10.1007/s10021-011-9512-0

Hayhoe, K. 2013. Development and dissemination of a high-resolution national climate change dataset. Final report for United States Geological Survey. Agreement number G10AC00582. Texas Tech University, Lubbock, Texas, USA.

Hijmans, R.J., and C.H. Graham. 2006. The ability of climate envelope models to predict the effect of climate change on species distributions. Global Change Biology 12: 2272-2281. doi: 10.1111/j.1365-2486.2006.01256.x

Idaho Interactive Numeric and Spatial Information Data Engine. 2011. Bias corrected statistical downscaling method datasets. University of Idaho, Moscow, USA. <http://cloud.insideidaho.org/data/epscor/dcs/ipccar4/bcsd/>. Accessed 16 May 2015.

Intergovernmental Panel on Climate Change. 2007a. Climate Change 2007: impacts, adaptation and vulnerability. Contribution of Working Group II. Cambridge University Press, Cambridge, England, United Kingdom, and New York, New York, USA.

Intergovernmental Panel on Climate Change. 2007b. Climate change 2007: the physical science basis. Contribution of Working Group I. Cambridge University Press, Cambridge, England, United Kingdom, and New York, New York, USA.

Jeschke, J.M., and D.L. Strayer. 2008. Usefulness of bioclimatic models for studying climate change and invasive species. Annals of the New York Academy of Sciences 1134: 1-24. doi: 10.1196/annals.1439.002

Kearney, M.R., B.A. Wintle, and W.P. Porter. 2010. Correlative and mechanistic models of species distribution provide congruent forecasts under climate change. Conservation Letters 3: 203-213. doi: 10.1111/j.1755-263X.2010.00097.x

Krawchuk, M.A., M.A. Moritz, M.-A. Parisien, J. Van Dorn, and K. Hayhoe. 2009. Global pyrogeography: the current and future distribution of wildfire. PLoS ONE 4: e5102. doi: 10.1371/ journal.pone.0005102

LANDFIRE. 2014. LANDFIRE Environmental Site Potential 1.4.0. Wildland Fire Science, Earth Resources Observation and Science Center, US Geological Survey, Sioux Falls, South Dakota, USA. <http://landfire.cr.usgs.gov/viewer/>. Accessed 9 December 2015.

Liu, C., P.M. Berry, T.P. Dawson, and R.G. Pearson. 2005. Selecting thresholds of occurrence in the prediction of species distributions. Ecography 28: 385-393. doi: 10.1111/ j.0906-7590.2005.03957.x

Manning, A.D., P. Gibbons, and D.B. Lindenmayer. 2009. Scattered trees: a complementary strategy for facilitating adaptive responses to climate change in modified landscapes? Journal of Applied Ecology 46: 915-919. doi: 10.1111/j.1365-2664.2009.01657.x

McGuire, J.L., J.J. Lawler, B.H. McRae, T.A. Nuñez, and D.M. Theobald. 2016. Achieving climate connectivity in a fragmented landscape. Proceedings of the National Academy of Sciences 113: 7195-7200. doi: 10.1073/pnas.1602817113 
McKenzie, D., A.E. Hessl, and L.K.B. Kellogg. 2006. Using neutral models to identify constraints on low-severity fire regimes. Landscape Ecology 21: 139-152. doi: 10.1007/s10980005-0147-4

Miller, R.F., R.J. Tausch, E.D. McArthur, D.D. Johnson, and S.C. Sanderson. 2008. Age structure and expansion of pinon-juniper woodlands: a regional perspective in the Intermountain West. Research Paper RMRS-RP-69, US Department of Agriculture, Forest Service, Rocky Mountain Research Station, Fort Collins, Colorado, USA.

Moritz, M.A., M.D. Hurteau, K.N. Suding, and C.M. D’Antonio. 2013. Bounded ranges of variation as a framework for future conservation and fire management. Annals of the New York Academy of Sciences 1286: 92-107. doi: 10.1111/nyas.12104

NatureServe. 2009. International ecological classification standard: terrestrial ecological classifications. NatureServe central databases. NatureServe, Arlington, Virginia, USA.

NOAA [National Oceanic and Atmospheric Administration] Geophysical Fluid Dynamics Laboratory. 2009. Ocean simulation based on MOM4-beta2 release, version 4. National Oceanic and Atmospheric Administration, Geophysical Fluid Dynamics Laboratory, Princeton, New Jersey, USA.

Parisien, M.-A., and M.A. Moritz. 2009. Environmental controls on the distribution of wildfire at multiple spatial scales. Ecological Monographs 79: 127-154. doi: 10.1890/07-1289.1

Parmesan, C. 2006. Ecological and evolutionary responses to recent climate change. Annual Review of Ecology Evolution and Systematics 37: 637-669. doi: 10.1146/annurev.ecolsys.37.091305.110100

Phillips, S.J., R.P. Anderson, and R.E. Schapire. 2006. Maximum entropy modeling of species geographic distributions. Ecological Modelling 190: 231-259. doi: 10.1016/j.ecolmodel.2005.03.026

Phillips, S.J., and M. Dudík. 2008. Modeling of species distributions with MAXENT: new extensions and a comprehensive evaluation. Ecography 31: 161-175. doi: 10.1111/j.0906-7590. 2008.5203.x

Phillips, S.J., M. Dudík, and R.E. Schapire. 2011. MAXENT software for modeling species niches and distributions, version 3.3.3k. American Museum of Natural History, New York, New York, USA.

PRISM. 2014. Prism Climate Working Group. Oregon State University, Corvallis, Oregon, USA. <http://www.prism.oregonstate.edu/>. Accessed 4 April 2015.

Sparks, J.C., M.C. Stambaugh, and E.L. Keith. 2012. Restoring fire suppressed Texas oak woodlands to historic conditions using prescribed fire. Pages 127-141 in: D.C. Dey, M.C. Stambaugh, S.L. Clark, and C.J. Schweitzer, editors. Proceedings of the 4th fire in eastern oak forests conference. General Technical Report NRS-P-102, US Department of Agriculture, Forest Service, Northern Research Station, Newtown Square, Pennsylvania, USA.

Stambaugh, M.C., R.P. Guyette, E.D. Stroh, M.A. Struckhoff, and J.R. Whittier. 2018. Future southcentral US wildfire probability due to climate change. Climatic Change: in press.

Stambaugh, M.C., R.P. Guyette, J.M. Marschall, and D.C. Dey. 2016. Scale dependence of oak woodland historical fire intervals: contrasting The Barrens of Tennessee and Cross Timbers of Oklahoma, USA. Fire Ecology 12: 65-84. doi: 10.4996/fireecology.1202065

Stroh, E.D., M.A. Struckhoff, M.C. Stambaugh, and R.P. Guyette. 2018. Fire and climate suitability for woody vegetation communities in the south central United States- data. US Geological Survey data release, https://www.doi.org/10.5066/F70P0XWB.

Swetnam, T.W., and J.L. Betancourt. 1990. Fire-Southern Oscillation relations in the southwestern United States. Science 249: 1017-1020. doi: 10.1126/science.249.4972.1017 
Teague, R., R. Borchardt, J. Ansley, B. Pinchak, J. Cox, J.K. Foy, and J. McGrann. 1997. Sustainable management strategies for mesquite rangeland: the Waggoner Kite project. Rangelands Archives 19: 4-8.

Thomas, C.D., A. Cameron, R.E. Green, M. Bakkenes, L.J. Beaumont, Y.C. Collingham, B.F.N. Erasmus, M.F. de Siqueira, A. Grainger, L. Hannah, L. Hughes, B. Huntley, A.S. van Jaarsveld, G.F. Midgley, L. Miles, M.A. Ortega-Huerta, A. Townsend Peterson, O.L. Phillips, and S.E. Williams. 2004. Extinction risk from climate change. Nature 427: 145-148. doi: 10.1038/nature02121

Turner, M, and W.H. Romme. 1994. Landscape dynamics in crown fire ecosystems. Landscape Ecology 9: 59-77. doi: 10.1007/BF00135079

Veblen, T.T., T. Kitzberger, and J. Donnegan. 2000. Climatic and human influences on fire regimes in ponderosa pine forests in the Colorado Front Range. Ecological Applications 10: 1178-1195. doi: 10.1890/1051-0761(2000)010[1178:CAHIOF]2.0.CO;2

Walther, G.R., E. Post, P. Convey, A. Menzel, C. Parmesan, T.J.C. Beebee, J.M. Fromentin, O. Hoegh-Guldberg, and F. Bairlein. 2002. Ecological responses to recent climate change. Nature 416: 389-395. doi: 10.1038/416389a

Watling, J.I., L.A. Brandt, F.J. Mazzotti, and S.S. Romañach. 2013. Use and interpretation of climate envelope models: a practical guide. University of Florida, Fort Lauderdale, Florida, USA.

Westerling, A.L., H.G. Hidalgo, D.R. Cayan, and T.W. Swetnam. 2006. Warming and earlier spring increase western US forest wildfire activity. Science 313: 940-943. doi: 10.1126/ science. 1128834

Wilson, T.B., R.H. Webb, and T.L. Thompson. 2001. Mechanisms of range expansion and removal of mesquite in desert grasslands of the southwestern United States. General Technical Report RMRS-GTR-81, US Department of Agriculture, Forest Service, Rocky Mountain Research Station, Ogden, Utah, USA.

Woodward, F.I., M.R. Lomas, and C.K. Kelly. 2004. Global climate and the distribution of plant biomes. Philosophical Transactions of the Royal Society B: Biological Sciences 359: 14651476. doi: $10.1098 /$ rstb.2004.1525 